\title{
Performance of Kalon herpes simplex virus 2 assay using dried blood spots among young women in Uganda
}

\begin{tabular}{|c|c|}
\hline $\begin{array}{l}\text { Authors: } \\
\text { Sam L. Nsobya } \\
\text { Paul C. Hewett } \\
\text { Sam Kalibala } \\
\text { Barbara S. Me }\end{array}$ & $\mathrm{nsch}^{3}$ \\
\hline \multicolumn{2}{|c|}{$\begin{array}{l}\text { Affiliations: } \\
{ }^{1} \text { Department of Pathology, } \\
\text { School of Biomedical Science, } \\
\text { Makerere University, } \\
\text { Kampala, Uganda }\end{array}$} \\
\hline \multicolumn{2}{|c|}{$\begin{array}{l}{ }^{2} \text { Population Council, } \\
\text { Washington, District of } \\
\text { Columbia, United States }\end{array}$} \\
\hline \multicolumn{2}{|c|}{$\begin{array}{l}{ }^{3} \text { Population Council, } \\
\text { New York, New York, } \\
\text { United States }\end{array}$} \\
\hline \multicolumn{2}{|c|}{$\begin{array}{l}\text { Corresponding author: } \\
\text { Paul Hewett, } \\
\text { phewett@popcouncil.org }\end{array}$} \\
\hline \multicolumn{2}{|c|}{$\begin{array}{l}\text { Received: } 24 \text { Feb. } 2016 \\
\text { Accepted: } 25 \text { May } 2016 \\
\text { Published: } 16 \text { Aug. } 2016\end{array}$} \\
\hline \multicolumn{2}{|c|}{$\begin{array}{l}\text { How to cite this article: } \\
\text { Nsobya SL, Hewett PC, } \\
\text { Kalibala S, Mensch BS. } \\
\text { Performance of Kalon herpes } \\
\text { simplex virus } 2 \text { assay using } \\
\text { dried blood spots among } \\
\text { young women in Uganda. Afr } \\
\text { J Lab Med. 2016;5(1), a429. } \\
\text { http://dx.doi.org/10.4102/ } \\
\text { ajlm.v5i1.429 }\end{array}$} \\
\hline \multicolumn{2}{|c|}{$\begin{array}{l}\text { Copyright: } \\
\text { (C) 2016. The Authors. } \\
\text { Licensee: AOSIS. This wo } \\
\text { is licensed under the } \\
\text { Creative Commons } \\
\text { Attribution License. }\end{array}$} \\
\hline \multicolumn{2}{|l|}{ Read online: } \\
\hline 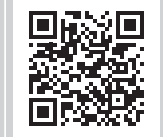 & $\begin{array}{l}\text { Scan this QR } \\
\text { code with your } \\
\text { smart phone or } \\
\text { mobile device } \\
\text { to read online. }\end{array}$ \\
\hline
\end{tabular}

This study evaluated the performance of the Kalon Biological HSV2 IgG enzyme-linked immunosorbent assay (Kalon Biological Ltd, Surrey, United Kingdom) on dried blood spots (DBS) of various dilutions compared with plasma from young women aged 18-24 years in Uganda. We estimated the sensitivity and specificity of three DBS dilutions using plasma as the reference. All three evaluated DBS dilutions yielded low sensitivities and specificities, with DBS 1:2 yielding the highest concurrence. Other herpes simplex virus type 2 assays should be examined with regard to their utility for testing DBS.

\section{Introduction}

Herpes simplex virus type 2 (HSV-2) causes lifelong infections in exposed individuals and is a useful cumulative marker for unprotected sex. HSV-2 infection has also been shown to be an important co-infection for HIV, facilitating HIV acquisition and transmission, and accelerating disease progression. ${ }^{1}$ In Uganda, it is estimated that about half of adults aged 15-59 years are infected with HSV-2. ${ }^{2}$

Numerous studies have outlined the usefulness of dried blood spots (DBS) for the serologic diagnosis of infectious diseases, as well as for large-scale seroprevalence studies. ${ }^{3,4,5,6,7}$ Since DBS do not require immediate refrigeration, occupy little space and are easily transported, they are an attractive means for biomarker-based studies, particularly in geographic settings with limited laboratory resources.

Recently-developed type-specific HSV antibody tests are based on the detection of antibodies to glycoprotein G1 (gG1), a marker for HSV-1 infection, and glycoprotein G2 (gG2), a marker for HSV-2 infection. ${ }^{8,9}$ Validation of DBS for immunoglobulin G (IgG)-based tests has been conducted using HSV-1-positive antibody samples from 22 healthy volunteers. ${ }^{10}$ Hogrefe, Ernst and Su reported that testing data using a single dilution of DBS eluates (1:4) with the HSV type-specific enzyme-linked immunosorbent assay (ELISA) method were similar to those of sera diluted to 1:101 using the standard HerpeSelect ${ }^{\circledR}$ ELISA (Focus Diagnostics, California, United States). ${ }^{10}$ The efficiency of using IgG eluted from DBS samples was found to be consistent with measurements of IgG concentrations in most corresponding serum samples.

However, results have been inconsistent when using the Kalon Biological HSV2 IgG ELISA assay (Kalon Biological Ltd, Surrey, United Kingdom; hereafter Kalon ELISA HSV2 assay) when measuring antibodies to gG2 with the same testing protocol. ${ }^{10}$ In a household survey conducted in 2010, sexual behavior data and DBS specimens were collected from young women aged 18-24 years in Kampala. ${ }^{11}$ When a 1:4 dilution was applied to our first 277 DBS specimens, the estimated HSV-2 prevalence was $2 \%$. This prevalence was significantly lower than that reported previously in the 2004-2005 Uganda HIV / AIDS Sero-Behavioural Survey (UHSBS), which found a prevalence of 21\% among women aged 15-19 years and 38\% among women aged 20-24 years. ${ }^{2}$ When an additional 10 DBS specimens from our sample of young women were further analysed using a dilution of 1:2, the prevalence of HSV-2 increased three-fold. ${ }^{11}$

In the study reported here, we examined the performance of the Kalon ELISA HSV2 assay using DBS and plasma samples from stored specimens previously collected during the 2004-2005 UHSBS. The DBS laboratory assessment was conducted in late 2010 and early 2011. The study goal was to examine whether HSV-2 testing results based on DBS at various dilution levels were concordant with plasma-based results obtained from the same participants. 


\section{Methods}

\section{Ethical considerations}

Participants who provided specimens to the 2004-2005 UHSBS consented to the long-term storage and future testing of their delinked blood specimens for which they would not receive results. We obtained additional permission for this study from the Uganda Ministry of Health. The study was also reviewed and approved by the Uganda Virus Research Institute's Institutional Review Board (GC/127/11/10/15) and the Population Council Institutional Review Board (protocol 433).

\section{Study population}

This study was conducted using existing stored DBS and plasma specimens from the 2004-2005 UHSBS. The UHSBS was a nationally-representative household-based survey that sampled 19656 adult respondents. The main objective of the UHSBS was to obtain national and sub-national estimates of HIV prevalence and selected indicators of HIV-related risk behaviours, programme coverage and HIV knowledge and attitudes. One of its specific objectives was to determine the magnitude and distribution of HIV and other sexuallytransmitted infections, such as HSV-2, in Uganda. ${ }^{2}$ The UHSBS estimated the national adult prevalence of HIV at $6.4 \%$ and that of HSV-2 at $44 \% .^{2}$

\section{Survey specimens and testing}

Survey participants had venous blood samples drawn into $4.5 \mathrm{ml}$ EDTA Vacutainer tubes, from which DBS were produced using Whatman SS903 specimen collection paper, air-dried overnight in plastic boxes and stored in lots of 20 separated by glassine paper in Ziploc bags containing desiccants. In the field, blood was centrifuged and the plasma was transferred to microvials. Plasma and DBS were transported periodically to a central laboratory in Entebbe for processing and storage at $-80^{\circ} \mathrm{C}$ (plasma) and $-20^{\circ} \mathrm{C}(\mathrm{DBS})$. The plasma and DBS samples for the UHSBS were tested for HSV-2 antibodies using the Kalon ELISA HSV2 assay within several weeks of collection. Results were classified as positive or negative using cutoffs as specified by the manufacturer.

\section{DBS validation study design}

For the purposes of this study, we randomly selected 110 stored DBS specimens from women aged 18-24 years whose plasmabased equivalents tested positive and 110 stored DBS specimens whose plasma-based equivalents tested negative using the Kalon ELISA HSV2 assay. Laboratory testing and analysis was conducted at the Molecular Research Laboratory in Kampala as part of the Makerere University-University of California, San Francisco Research Collaboration on 2 May 2011.

From each of these 220 DBS, a $6 \mathrm{~mm}$-diameter $\left(28 \mathrm{~mm}^{2}\right)$ disk, containing approximately $50-75 \mu \mathrm{L}$ of blood per spot, was punched out from the filter paper and soaked overnight at $4{ }^{\circ} \mathrm{C}$ in $150 \mu \mathrm{L}$ of phosphate-buffered saline ( $\mathrm{pH}$ 7.4). After the overnight elution step, the eluates were diluted at three different levels, 1:4, 1:3 and 1:2. Each specimen was tested in triplicate with the Kalon ELISA HSV2 assay, as directed by the manufacturer's instructions.

\section{Data analysis}

Frequencies of reactivity, non-reactivity, sensitivity and specificity with $95 \%$ confidence intervals were generated using SAS ${ }^{\circledR}$ software, version 9.3 (SAS Institute Inc., Cary, North Carolina, United States, 2011). DBS-based estimates of sensitivity and specificity were obtained using the plasmabased results as the reference. We determined the dilution level for DBS-based HSV-2 testing that yielded the highest (relative) sensitivity and specificity.

\section{Results}

The final sample size included 210 individuals due to missing test results for 10 DBS. Of the 210 plasma specimens, 104 (49.5\%) were reactive and 106 (50.5\%) were non-reactive for HSV-2 antibodies (Table 1). The DBS 1:2 dilution yielded 116 $(55.2 \%)$ reactive and $94(44.8 \%)$ non-reactive results. DBS 1:3 produced $124(59.0 \%)$ reactive and $86(41.0 \%)$ non-reactive results, whereas DBS 1:4 yielded 110 (52.4\%) reactive and 100 $(47.6 \%)$ non-reactive results.

The 1:2 ratio of buffer and eluate yielded the highest sensitivity (84.6\%) and specificity (73.6\%) (Table 2). The 1:3 dilution had the next-highest sensitivity $(82.7 \%)$, but had the lowest specificity (64.2\%). The 1:4 dilution showed the lowest sensitivity $(73.1 \%)$ and a specificity of $67.9 \%$. Overall, 127 $(60.5 \%)$ of the 210 specimens had concordant results between plasma and all three DBS dilutions (not shown in the tables). Of the 127 concordant results, 69 (54.3\%) were concordant positive and $58(45.7 \%)$ were concordant negative. A total of $83(39.5 \%)$ cases had a discordant result between plasma and at least one of the DBS dilutions. Of the 83 discordant results, $35(42.2 \%)$ were discordant positive and $48(57.8 \%)$ were discordant negative.

TABLE 1: HSV-2 seropositivity for plasma-based and DBS dilution-based assays using the Kalon ELISA HSV2 assay among young women in Uganda, 2004-2005. $\dagger$

\begin{tabular}{|c|c|c|c|c|c|c|c|c|c|}
\hline \multirow[t]{2}{*}{ Plasma } & \multicolumn{3}{|c|}{ DBS 1:2 } & \multicolumn{3}{|c|}{ DBS 1:3 } & \multicolumn{3}{|c|}{ DBS 1:4 } \\
\hline & Non-reactive $:$ & Reactive $\S$ & Total $\boldsymbol{n}(\%)$ & Non-reactive ${ }^{\ddagger}$ & Reactive $^{\S}$ & Total $n(\%)$ & Non-reactive ${ }^{\ddagger}$ & Reactive§ & Total $n(\%)$ \\
\hline Negativeף & 78 & 28 & $106(50.5)$ & 68 & 38 & $106(50.5)$ & 72 & 34 & $106(50.5)$ \\
\hline Positive $\uparrow \dagger$ & 16 & 88 & $104(49.5)$ & 18 & 86 & $104(49.5)$ & 28 & 76 & $104(49.5)$ \\
\hline Total $n(\%)$ & $94(44.8)$ & $116(55.2)$ & $210(100.0)$ & $86(41.0)$ & $124(59.0)$ & $210(100.0)$ & $100(47.6)$ & $110(52.4)$ & $210(100.0)$ \\
\hline
\end{tabular}

DBS, dried blood spots; HSV-2, herpes simplex virus 2.

$\dagger$, Women were aged 18-24 years, $N=210$; $\$$, Non-reactive, DBS negative for HSV-2 antibodies; $\S$, Reactive, DBS positive for HSV-2 antibodies; $\uparrow$, Negative, plasma negative for HSV-2 antibodies; $\dagger$, Positive, plasma positive for HSV-2 antibodies. 
TABLE 2: Relative sensitivity, specificity and $95 \%$ confidence intervals of dried bloodspot dilutions tested with the Kalon ELISA HSV2 assay compared with plasma among young women in Uganda, 2004-2005.†

\begin{tabular}{lccc}
\hline Dilution & Sensitivity \% (95\% Cl) & Specificity \% (95\% Cl) & Overall concordance \% \\
\hline DBS 1:2 & $84.6(76.2-90.9)$ & $73.6(64.1-81.7)$ & 79.0 \\
DBS 1:3 & $82.7(74.0-89.4)$ & $64.2(54.3-73.2)$ & 73.3 \\
DBS 1:4 & $73.1(63.5-81.3)$ & $67.9(58.2-76.7)$ & 70.5 \\
\hline
\end{tabular}

DBS, dried blood spots.

$\dagger$, Women were aged $18-24$ years, $N=210$.

\section{Discussion}

The Kalon ELISA HSV2 assay has been shown to be sensitive and specific for HSV-2 diagnosis using plasma. ${ }^{2,12}$ In our study, a dilution of 1:2 showed the highest sensitivity and specificity compared with the 1:3 and 1:4 dilution levels. This estimated sensitivity and specificity is low relative to the plasma-based reference results. Specifically, our findings differ from the estimated higher sensitivity and specificity found in a South African population which used the HerpeSelect ELISA serological assay. ${ }^{13}$ However, earlier studies evaluating the plasma-based HerpeSelect ELISA test in sub-Saharan populations suggested a lower specificity than the plasmabased Kalon ELISA HSV2 assay. ${ }^{14}$

In addition, patterns of reactivity varied by dilution level. Although not the optimal dilution based on sensitivity or specificity, DBS 1:3 had the highest proportional reactivity to HSV-2 antibodies (59.0\%). All three dilutions yielded higher frequencies of reactivity than plasma (49.5\%), specifically DBS 1:2 (55.2\%), DBS 1:3 (59.0\%) and DBS 1:4 (52.4\%). We found low concordance between plasmabased and DBS-based results, which contrasts with the high concordance reported by Hogrefe et al. using the HerpeSelect assay. ${ }^{10}$

\section{Limitations}

There are several limitations in our study. The sampling frame was limited to young women aged 18-24 years in Uganda; thus, our results are not generalisable to men or older adults. Additionally, the sample size was relatively small. Further, we did not compare the quantity of IgG in the DBS punch specimens to that in plasma specimens. Finally, this study only used the Kalon ELISA HSV2 assay to evaluate DBS for HSV-2 diagnosis. Other HSV-2 assays, such as the HerpeSelect 2 ELISA IgG and Biokit HSV2 Rapid Assay are used in African countries and need to be further evaluated to compare their utility with DBS.

\section{Conclusion}

In summary, our study examined the performance of the Kalon ELISA HSV2 assay, using DBS in a population of young women in Uganda. DBS testing with the Kalon ELISA HSV2 assay revealed relatively low sensitivity and specificity compared with plasma-based results on the same individuals. While DBS would be an appealing and relatively simple means for biomarker-based studies, particularly in resource-constrained settings, the accuracy of this testing format would need to be substantially improved before its use could be recommended for epidemiological studies.

\section{Acknowledgements}

The authors would like to thank Angele Marandet and Wolfgang Hladik at the United States Centers for Disease Control for their support and encouragement in the development of the manuscript. We also thank Joshua Musinguzi of the Ministry of Health, AIDS Control Programme in Uganda for his assistance in design and execution of the study.

\section{Competing interests}

The authors declare that they have no financial or personal relationship(s) which may have inappropriately influenced them in writing this article.

\section{Sources of support}

The study was funded by the National Institutes of Health grant number R01 HD 047764 S1, Barbara S. Mensch Principal Investigator, Paul C. Hewett, Co-Principal Investigator.

\section{Author contributions}

S.L.N. drafted the manuscript, which was reviewed and contributed to by P.C.H., S.K. and B.S.M. S.L.N. oversaw the testing of specimens in the laboratory and the reporting of the test results. S.L.N. and P.C.H. contributed to the analysis of the results. B.S.M. and P.C.H. conceived of the original study, with S.L.N. and S.K. assisting with its design and execution.

\section{References}

1. Laeyendecker O, Henson C, Gray RH, et al. Performance of a commercial, typespecific enzyme-linked immunosorbent assay for detection of herpes simplex virus type 2-specific antibodies in Ugandans. J Clin Microbiol. 2004;42(4): 1794-1796. http://dx.doi.org/10.1128/JCM.42.4.1794-1796.2004

2. Macro O. Uganda HIV/AIDS sero-behavioural survey: 2004-2005. Ministry of Health; 2006.

3. Bailey NM, Cunningham MP, Kimber CD. The indirect fluorescent antibody technique applied to dried blood, for use as a screening test in the diagnosis of human trypanosomiasis in Africa. Trans R Soc Trop Med Hyg. 1967;61(5):696-700. http://dx.doi.org/10.1016/0035-9203(67)90135-6

4. Beebe JL, Briggs LC. Evaluation of enzyme-linked immunoassay systems for detection of human immunodeficiency virus type 1 antibody from filter paper disks impregnated with whole blood. J Clin Microbiol. 1990;28(4):808-810.

5. Brody JA, McAlister R, Haseley R, Lee P. Use of dried whole blood collected on filter paper disks in adenovirus complement fixation and measles hemagglutination inhibition tests. J Immunol. 1964;92(6):854-857.

6. Jafri HS, Torrico F, Noh JC, et al. Application of the enzyme-linked immunoelectrotransfer blot to filter paper blood spots to estimate seroprevalence of cysticercosis in Bolivia. Am J Trop Med Hyg. 1998;58(3):313-315.

7. Takkouche B, Iglesias J, Alonso-Fernandez JR, Fernandez-Gonzalez C, Gestal-Otero JJ. Detection of Brucella antibodies in eluted dried blood: A validation study. Immuno Lett. 1995;45(1-2):107-108. http://dx.doi.org/10.1016/0165-2478(94)00247-O 
8. Ashley RL, Wald A. Genital herpes: Review of the epidemic and potential use of type-specific serology. Clin Microbiol Rev. 1999;12(1):1-8.

9. Ashley R. Type-specific antibodies to HSV-1 and -2: Review of methodology. Herpes. 1998;5:33-38.

10. Hogrefe WR, Ernst C, Su X. Efficiency of reconstitution of immunoglobulin $G$ from blood specimens dried on filter paper and utility in herpes simplex virus typespecific serology screening. Clin Diagn Lab Immunol. 2002;9(6):1338-1342. http://dx.doi.org/10.1128/cdli.9.6.1338-1342.2002

11. Kelly CA, Hewett PC, Mensch BS, et al. Using biomarkers to assess the validity of sexual behavior reporting across interview modes among young women in
Kampala, Uganda. Stud Fam Plann. 2014;45(1):43-58. http://dx.doi.org/10.1111/ j.1728-4465.2014.00375.x
12. Lingappa J, Nakku-Joloba E, Magaret A, et al. Sensitivity and specificity of herpes simplex virus-2 serological assays among HIV-infected and uninfected urban simplex virus-2 serological assays among HIV-infected and uninfected urban
Ugandans. Int J STD AIDS. 2010;21(9):611-616. http://dx.doi.org/10.1258/ ijsa.2009.008477

13. Delany-Moretlwe S, Jentsch $\mathrm{U}$, Weiss $\mathrm{H}$, et al. Comparison of focus HerpesSelect and Kalon HSV-2 gG2 ELISA serological assays to detect herpes simplex virus type 2 antibodies in a South African population. Sex Transm Infect. 2010:86(1):46-50. http://dx.doi.org/10.1136/sti.2009.036541

14. Smith JS, Bailey RC, Westreich DJ, et al. Herpes simplex virus type 2 antibody detection performance in Kisumu, Kenya, using the Herpeselect ELISA, Kalon ELISA, Western blot and inhibition testing. Sex Transm Infect. 2009;85(2):92-96. http://dx.doi.org/10.1136/sti.2008.031815 